\title{
MATHEMATICAL MODEL OF THE MODIFIED ROLL FOR SPIRAL BEVEL GEARS MILLING MACHINES
}

\author{
Piotr Skawiński, Marek Kret
}

\begin{abstract}
$\mathrm{Su} \mathrm{m}$ mary
This paper contains the description of conventional roll modification mechanism used for spiral bevel gears generation and presents several possible solutions for the implementation of this mechanism using mathematical equations. Accuracy of each method has been compared with respect to nominal values, and mathematical derivation has been discussed. Possible practical application in numerical machine control units and geometric simulation environments has been outlined.
\end{abstract}

Keywords: spiral bevel gears, CNC machines, Modified Roll, SGM

\section{Matematyczny model modyfikacji odtaczania frezarek do kół stożkowych o kołowo-łukowej linii zęba}

$$
\text { Streszczenie }
$$

W pracy przedstawiono ideę mechanizmu modyfikacji odtaczania dla kół stożkowych o kołowołukowej linii zęba. Przedstawiono również kilka możliwości realizacji tego mechanizmu za pomocą równań matematycznych. Prowadzono analizę dokładności każdej metody z uwzględnieniem wartości nominalnych oraz omówiono sposoby ich matematycznego wyprowadzenia. Podano możliwości ich praktycznego zastosowania w sterownikach numerycznych urządzeń używanych do obróbki kół stożkowych, także w geometrycznych środowiskach symulacyjnych.

Słowa kluczowe: koła zębate stożkowe, obrabiarki sterowane numerycznie, modyfikacja odtaczania, SGM

\section{Introduction}

Bevel gearsets are one of the basic power and motion transfer mechanisms operating in modern automotive and aircraft industry. They allow to design machineries with non-parallel and crossing axles that has a tremendous impact on product optimization process. Although spiral bevel gears have a great number of operational advantages, their design, manufacturing and optimization processes require substantial engineering skills. They are very time and cost consuming what is essential when deciding to launch a new product.

\footnotetext{
Address: Piotr SKAWINSKI, DSc. Eng., Marek KRET, M.Sc., Warsaw University of Technology, Faculty of Automotive and Construction Machinery Engineering, 02-524 Warsaw, Narbutta 84, psk@simr.pw.edu.pl
} 
There are several methods of manufacturing spiral bevel gears on the basis of which numbers of different machines using various tools have been developed. Of course modern production methods are focused mainly on the CNC (Computerized Numerical Control) machines that have the capability of unifying different manufacturing methods on a single numerically controlled machine. Each of these methods produces specific shape of the teeth and have different performance characteristics [1-7].

Let us focus on one of the most widely used bevel gears cutting method in the industry that is Gleason's SGM (Spiral Generated Modified Roll). Pinion is generated using a single indexing cutting process that utilizes the roll modification mechanism with a separate cutterhead for each, convex and concave, tooth face. This "modified roll" process consists of acceleration and deceleration of a roll movement during tooth face generation which leads to a head and heel additional undercut (Fig. 1). The modification of pinion flank geometry results from a tooth shape adjustment that is necessary for correct mesh with a straight flank gear. Other case is the usage of so called numbered blades, where number represents the pressure angle of its cutting edge, that lead to the pressure angle distortion and has to be compensated with a roll movement modification. It is important to mention that the gear is acknowledged to be fixed and all of the pinion-gear pair modifications are applied only to the pinion.

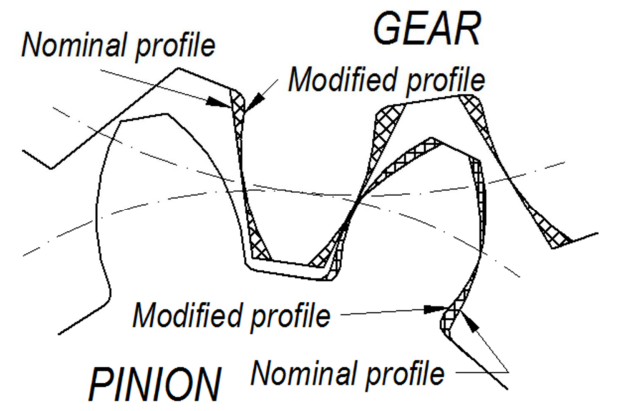

Fig. 1. Idea of the face flank modification in the Gleason SGM method

\section{Modified roll mechanism mathematical models}

In a conventional process the circumferential movement modification $\Delta \Theta_{K}$ is obtained by means of special mechanisms composed of angle-eccentric elements coupled with the worm and modified roll ratio transmission gears (Fig. 2). Kinematic chain that couples cradle rotation with the worm-wheel rotation is described by the following equation: 
Mathematical model of the modified roll ...

$$
\Theta_{R C}=\Theta_{0} \cdot i_{M} \cdot C
$$

where: $\Theta_{R C}$ - worm-wheel rotation angle, $\Theta_{0}$ - cradle rotation angle, $i_{M}-$ modified roll ratio, $C=C_{1} \cdot C_{2} \cdot C_{3} \cdot \ldots \cdot C_{n}$ - constant gear sets transmission ratio.

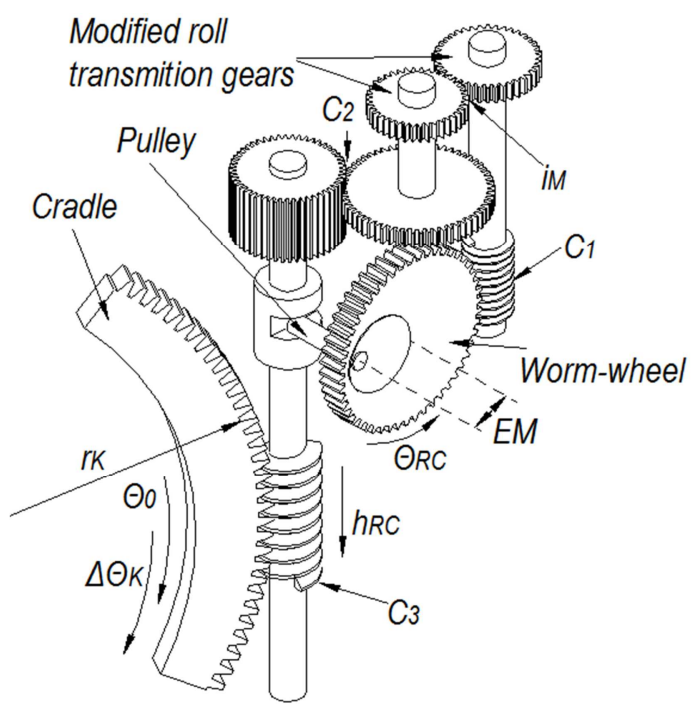

Fig. 2. Typical conventional roll modification mechanism

When worm-wheel rotation occurs, the worm in the worm gear transmission set is pushed along its axle by the pulley and generates the modification roll component of the cradle movement. This axial movement is given by the equation:

$$
h_{R C}=E_{M} \cdot\left(1-\cos \Theta_{R C}\right)
$$

where $E_{M}$ is the eccentricity value of a pulley axis related to the worm-wheel axis. Utilizing the rolling radius of the cradle worm wheel $\left(r_{K}\right)$, we are able to obtain the cradle rotation angle that derives from the worm axial movement:

$$
\Delta \Theta_{K}=\frac{h_{R C}}{r_{K}}
$$


During the spiral bevel gear machining process design it is crucial to maintain the totalworm-wheel rotation angle $\Theta_{R C}$ below the value of $100 \mathrm{deg}$. In practice, it means that the worm-wheel rotation per each side from its middle position should be no greater than $50 \mathrm{deg}$. By the middle position we mean the situation in which the cradle rotation angle derived from the roll modification mechanism is equal to zero $\Delta \Theta_{K}=0$. The origin of this requirement comes from the mathematical simplifications that has been applied to the conventional calculation algorithm. Its utilization provides a negligible mistake between the mathematical roll modification model and its mechanical representation on the real machine. This topic will be discussed in details later in this article. In order to satisfy this requirement production process, a design engineer needs to determine the transmission ratio between the cradle wheel and the worm-wheel. This ratio is called modified roll ratio and can be defined by the inequality:

$$
i_{M} \leq \frac{100 \cdot \operatorname{deg}}{\Theta_{0} \cdot C}
$$

Possible discrepancies resulting from a wrong worm-wheel rotation range $\Theta_{R C}$ are presented in Fig. 3. They lead to an erroneous flank geometry and at the best, to the contact pattern misalignment between pinion and gear. In the worst case, this mistake can lead to the machine damage. 


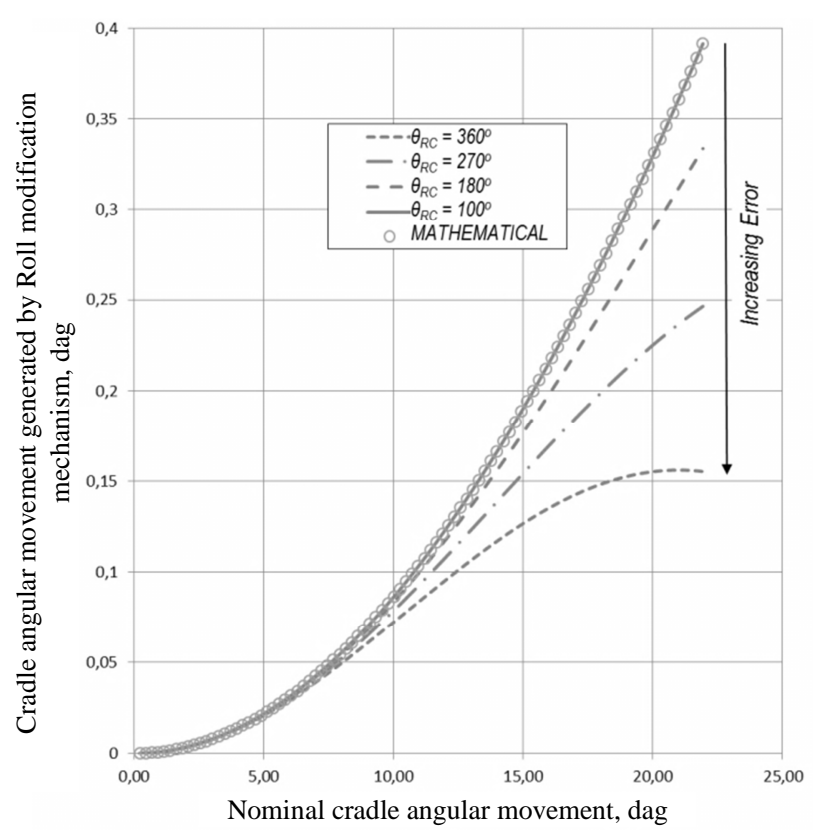

Fig. 3. Graphical representation of improper worm-wheel rotation range setup

On conventional machines, the adjustable gear assembly has to be coupled to produce the transmission radio as close to the theoretical value as possible. Inaccurate selection may cause serious differences in roll modification comparing to the values assumed at the gear geometry design level. Some more advanced machines have a capability of worm-wheel pulley eccentricity $E_{M}$ setup that partially accommodates the discrepancy resulting from the $i_{M}$ transmission selection.

For numerically driven machines as well as forgeometrical simulation programs we can develop more accurate approach. Based on the previous assumption we can derive the maximum allowablemodified roll ratio:

$$
i_{M \max }=\frac{100 \cdot \mathrm{deg}}{\Theta_{0} \cdot C}
$$

According to the Figure number 3 it corresponds to the situation that the worm-wheel rotates in the desired $\pm 50 \mathrm{deg}$. interval. Because in the numerical approach we do not have to select the transmission by the gears availability table, we do not lose any accuracy. The next step is to calculate the pulley eccentricity value $E_{M}$ from the relation: 


$$
k_{M}=C_{M} \cdot E_{M} \cdot i_{M}^{2}
$$

where $k_{M}$ is the roll modification factor that is obtained from the basic technology calculation results. Reordering the given formula will give us the desired equation:

$$
E_{M}=\frac{C_{M}}{i_{M}^{2}}
$$

where $C_{M}$ is a value specific to a given machine tool and is defined as:

$$
C_{M}=\frac{C^{2}}{2 \cdot r_{K}}
$$

When we know all of the input values we can introduce them to the equation that describes the complete cradle rotation angle that is derived from the roll modification mechanism:

$$
\Delta \Theta_{K}=\frac{E_{M} \cdot\left(1-\cos \Theta_{R C}\right)}{r_{K}}
$$

From this point we have several ways for further evaluation, first of which is the cradle angular movement time frame approach. Table 1 presents the complete computational process for the specific gear set (Pinion/Gear ration: 18/43, Axle angle: 70deg., CC flank - detailed basic technology data obtained from KONTEPS - bevel gears design software is presented in Tab. 2) and using actual bevel gear generator geometrical data (Saratov 528). Now we can plot the cradle circumferential movement derived from the modification mechanism against its nominal angular position (Fig. 4). From the theory of the teeth flank modification developed by Gleason we know that the surface should be superimposed with a polynomial of 4-th order, however the described methodology refers to the machines equipped with mechanism that allows only 2-nd order representation. It has been proved by experience, that this level of approximation is sufficient for high quality gear sets manufacturing. On this basis it has been assumed to the best fit of the cradle modification movement vs. cradle nominal movement curve with the cubic function (Fig. 4). This relation can be directly applied in the CNC bevel gears generators as well as in the geometrical simulation environments and it is given by the equation: 
Mathematical model of the modified roll ...

$$
\Delta \Theta_{K}(t)=A \cdot \Theta_{0}^{2}(t)+B \cdot \Theta_{0}(t)
$$

where $A$ and $B$ are the cubic function coefficients obtained from the 2-nd order trend line.

Table 1. Cradle angular movement time the frame approach data for 18/43-70 gear set

\begin{tabular}{|c|c|c|c|c|c|c|c|c|c|}
\hline 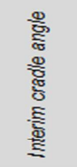 & 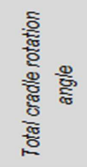 & 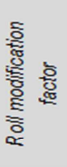 &  & 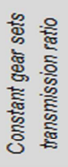 & 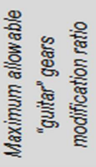 & 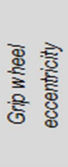 &  & 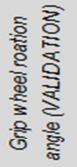 & 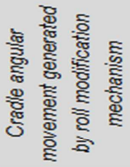 \\
\hline variable & \multicolumn{2}{|c|}{$\begin{array}{c}\text { Basic Technology } \\
\text { Input }\end{array}$} & \multicolumn{2}{|c|}{$\begin{array}{l}\text { Saratov } 528 \\
\text { Geometry }\end{array}$} & (5) & (7) & (8) & (1) & (9) \\
\hline $\begin{array}{l}\theta_{0}(t) \\
\text { Ideql }\end{array}$ & $\begin{array}{c}\theta_{0} \\
\text { [deq] }\end{array}$ & $\begin{array}{l}k_{M} \\
{[1]} \\
\end{array}$ & $\begin{array}{c}r_{K} \\
{[\mathrm{~mm}]}\end{array}$ & $\begin{array}{c}C \\
{[1]}\end{array}$ & $\begin{array}{l}i_{\operatorname{Mmax}} \\
{[1]}\end{array}$ & $\begin{array}{l}E_{M} \\
{[\mathrm{mml}}\end{array}$ & $\begin{array}{c}C_{M} \\
{[1 / \mathrm{mm}]}\end{array}$ & $\begin{array}{l}\theta_{R C} \\
{[d e q]} \\
\end{array}$ & $\begin{array}{c}\theta_{K} \\
\text { [deq] }\end{array}$ \\
\hline 1,06 & 42,52 & 0,074 & 600,000 & 2,083 & 1,129 & 16,055 & 0,00362 & 2,500 & 0,001 \\
\hline 2,13 & 42,52 & 0,074 & 600,000 & 2,083 & 1,129 & 16,055 & 0,00362 & 5,000 & 0,006 \\
\hline 3,19 & 42,52 & 0,074 & 600,000 & 2,083 & 1,129 & 16,055 & 0,00362 & 7,500 & 0,013 \\
\hline 4,25 & 42,52 & 0,074 & 600,000 & 2,083 & 1,129 & 16,055 & 0,00362 & 10,000 & 0,023 \\
\hline 1,06 & 42,52 & 0,074 & 600,000 & 2,083 & 1,129 & 16,055 & 0,00362 & 2,500 & 0,001 \\
\hline 2,13 & 42,52 & 0,074 & 600,000 & 2,083 & 1,129 & 16,055 & 0,00362 & 5,000 & 0,006 \\
\hline 3,19 & 42,52 & 0,074 & 600,000 & 2,083 & 1,129 & 16,055 & 0,00362 & 7,500 & 0,013 \\
\hline 4,25 & 42,52 & 0,074 & 600,000 & 2,083 & 1,129 & 16,055 & 0,00362 & 10,000 & 0,023 \\
\hline 5,32 & 42,52 & 0,074 & 600,000 & 2,083 & 1,129 & 16,055 & 0,00362 & 12,500 & 0,036 \\
\hline 6,38 & 42,52 & 0,074 & 600,000 & 2,083 & 1,129 & 16,055 & 0,00362 & 15,000 & 0,052 \\
\hline
\end{tabular}

Table 2. Detailed basic technology data obtained from KONTEPS

PINION - FINISHING - CONCAVE FLANK 18/43-70 - GENERATED GEAR

\begin{tabular}{|l|c|c|}
\hline CUTER DIAMETER & $\mathrm{D}_{0}$ & $153.162 \mathrm{~mm}$ \\
\hline RADIAL SETTING & $\mathrm{U}$ & $68.573 \mathrm{~mm}$ \\
\hline ANGULAR SETTING & $\mathrm{Q}$ & $86^{\circ} 40^{\prime}$ \\
\hline MACHINE ROOT ANGLE & $\delta_{\mathrm{M}}$ & $16^{\circ} 48^{\prime}$ \\
\hline HEAD SETTING & $\mathrm{X}_{\mathrm{p}}$ & $-1.373 \mathrm{~mm}$ \\
\hline SLIDING BASE & $\mathrm{X}_{\mathrm{B}}$ & $.532 \mathrm{~mm}$ \\
\hline VERTICAL OFFSET & $\mathrm{A}$ & $6.293 \mathrm{~mm}$ \\
\hline RATIO OF ROLL & $\mathrm{R}_{\mathrm{a}}$ & .317 \\
\hline MODIFIED ROLL COEFFICIENT & $\mathrm{K}_{\mathrm{M}}$ & .074 \\
\hline
\end{tabular}




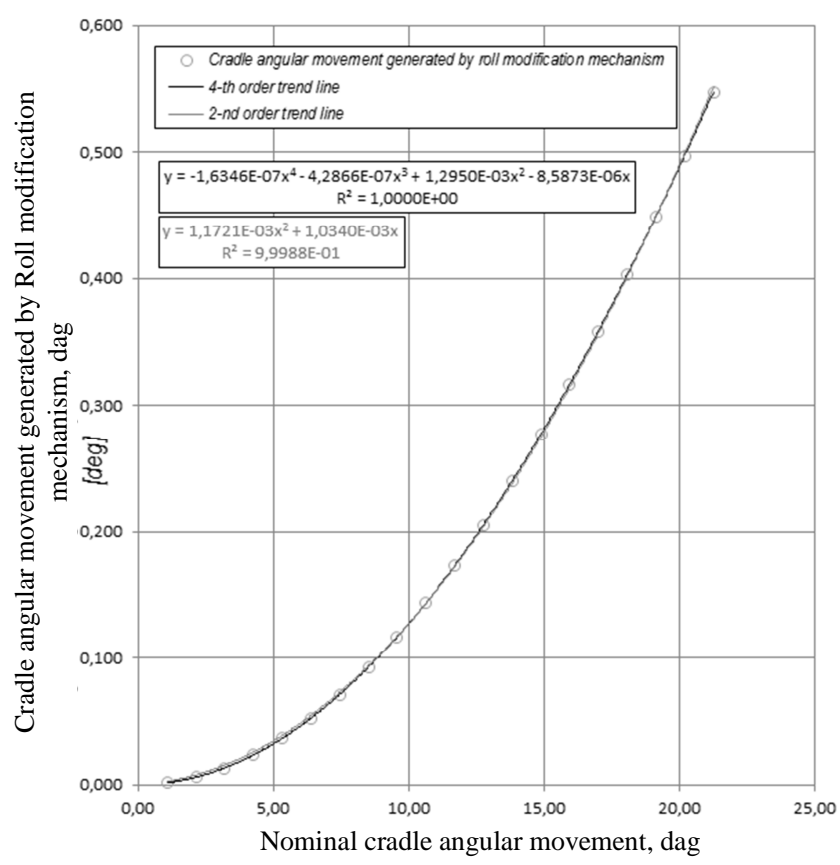

Fig. 4. Cradle angular movement time frame approach best fit with the polynomial function

The biggest disadvantage of this approach is that the calculation algorithm and best fit procedure have to be repeated for each gear being analyzed.

During a series of experiments certain regularity between cubic function coefficients $(A$ and $B)$ and basic technology parameters $\left(k_{M}\right.$ and $\left.\Theta_{0}\right)$ has been noticed and developed into the second, more comprehensive approach of roll movement modification evaluation (Tab. 3). It has been determined that the coefficient $a$ is dependent only on $k_{M}$ and can be characterized with an expression:

$$
A=1.58382 E-2 \cdot k_{M}
$$

whereas coefficient $b$ is dependent also only on $k_{M}$, but it's additionally scaled by $\Theta_{0}$ and can be described by expression:

$$
B=3.28617 E-4 \cdot k_{M} \cdot \Theta_{0}
$$


Mathematical model of the modified roll ...

Table 3. Regularity observed during a series of experiments

\begin{tabular}{|c|c|c|c|c|c|c|c|c|c|c|c|}
\hline$\theta_{0}$ & $k_{M}$ & $\begin{array}{c}a-\theta_{0}(t)^{2} \\
\text { coefficient }\end{array}$ & $\begin{array}{l}b-\theta_{0}(t) \\
\text { coefficient }\end{array}$ & $b / \theta_{0}$ & $\theta_{0}$ & $k_{M}$ & $\begin{array}{c}a-\theta_{0}(t)^{2} \\
\text { coefficient }\end{array}$ & $\begin{array}{c}\text { a coeff. } \\
\text { DIFFERENCE }\end{array}$ & $\begin{array}{l}b-\theta_{0}(t) \\
\text { coefficient }\end{array}$ & $b / \theta_{0}$ & $\begin{array}{c}b / \theta_{0} \\
\text { DIFFERENCE }\end{array}$ \\
\hline 10 & 0,00 & $0,000 E+00$ & $0,000 E+00$ & $000 E+00$ & 20 & 0,00 & $0,000 E+00$ & $0,0 \%$ & $0,000 E+00$ & $0,000 E+00$ & $0,0 \%$ \\
\hline 10 & 0,01 & $1,584 E-04$ & $3,286 E-05$ & 3,286E-06 & 20 & 0,01 & $1,584 E-04$ & $0,0 \%$ & 6,572E-05 & $3,286 E-06$ & $0,0 \%$ \\
\hline 10 & 0,02 & $3,168 E-04$ & $6,572 E-05$ & 6,572E-06 & 20 & 0,02 & $3,168 E-04$ & $0,0 \%$ & $1,314 E-04$ & $6,572 E-06$ & $0,0 \%$ \\
\hline 10 & 0,03 & $4,752 E-04$ & $9,859 E-05$ & 9,859E-06 & 20 & 0,03 & $4,752 E-04$ & $0,0 \%$ & 1,972E-04 & $9,859 E-06$ & $0,0 \%$ \\
\hline 10 & 0,04 & $6,335 E-04$ & $1,314 E-04$ & 1,314E-05 & 20 & 0,04 & $5 E-04$ & $0,0 \%$ & $8 E-04$ & $=-05$ & $0,0 \%$ \\
\hline 10 & 0,05 & $7,919 E-04$ & 1,643E-04 & 1,643E-05 & 20 & 0,05 & 7,919E-04 & $0,0 \%$ & 3,286E-04 & $1,643 E-05$ & $0,0 \%$ \\
\hline 10 & 0,06 & $9,503 E-04$ & 1,972E-04 & 1,972 & 20 & 0,06 & $3 E-04$ & $\%$ & $3 E-04$ & -05 & $0,0 \%$ \\
\hline 10 & 0,07 & $1,109 E-03$ & $2,300 E-04$ & 2,300E-05 & 20 & 0,07 & $1,109 E-03$ & $0,0 \%$ & $4,600 E-04$ & $E-05$ & $0,0 \%$ \\
\hline 10 & 0,08 & $1,267 E-03$ & 2,629E-04 & 2,629E-05 & 20 & 0,08 & 1,267E-03 & $0,0 \%$ & 5,258E-04 & $2,629 E-05$ & $0,0 \%$ \\
\hline 10 & 0,09 & $1,425 E-03$ & 2,958E-04 & 2,95 & 20 & 0,09 & $1,425 E-03$ & $0,0 \%$ & 5,916E-04 & -05 & $0,0 \%$ \\
\hline 10 & 0,10 & $1,584 E-03$ & $3,286 E-04$ & 3,286E-05 & 20 & 0,10 & $1,584 E-03$ & $0,0 \%$ & 6,572E-04 & $3,286 E-05$ & $0,0 \%$ \\
\hline 10 & 0,20 & $3,168 E-03$ & $6,572 E-04$ & 6,572E-05 & 20 & 0,20 & $3,168 E-03$ & $0,0 \%$ & $1,314 E-03$ & $6,570 E-05$ & $0,0 \%$ \\
\hline 10 & 0,30 & $4,752 E-03$ & $9,859 E-04$ & $9,859 E-05$ & 20 & 0,30 & $4,752 E-03$ & $0,0 \%$ & 1,972E-03 & $9,859 E-05$ & $0,0 \%$ \\
\hline 10 & 0,40 & $6,335 E-03$ & $1,314 E-03$ & 1,314E-04 & 20 & 0,40 & $6,335 E-03$ & $0,0 \%$ & $2,628 E-03$ & E-04 & $0,0 \%$ \\
\hline 10 & 0,50 & $7,919 E-03$ & $1,643 E-03$ & 1,643E-04 & 20 & 0,50 & 7,919E-03 & $0,0 \%$ & $3,286 E-03$ & $1,643 E-04$ & $0,0 \%$ \\
\hline 10 & 0,60 & $9,503 E-03$ & $1,972 E-03$ & 1,972E-04 & 20 & 0,60 & 9,503E-03 & $0,0 \%$ & 3,944E-03 & $1,972 E-04$ & $0,0 \%$ \\
\hline 10 & 0,70 & $1,109 E-02$ & $2,300 E-03$ & 2,300E-04 & 20 & 0,70 & 1,109E-02 & $0,0 \%$ & $4,600 E-03$ & $2,300 E-04$ & $0,0 \%$ \\
\hline 10 & 0,80 & $1,267 E-02$ & $2,629 E-03$ & 2,629E-04 & 20 & 0,80 & 1,267E-02 & $0,0 \%$ & $5,258 \mathrm{E}-03$ & $2,629 E-04$ & $0,0 \%$ \\
\hline 10 & 0,90 & $1,425 E-02$ & $2,958 E-03$ & 2,958E-04 & 20 & 0,90 & $1,425 E-02$ & $0,0 \%$ & 5,916E-03 & $2,958 E-04$ & $0,0 \%$ \\
\hline 10 & 1,00 & $1,584 E-02$ & $3,286 E-03$ & $3,286 E-04$ & 20 & 1,00 & 1,584E-02 & $0,0 \%$ & 6,572E-03 & $3,286 E-04$ & $0,0 \%$ \\
\hline
\end{tabular}

This approach enables us to avoid excessive side calculations for each gear set and gives us the universal and neat solution. The roll modification movement function can be characterized with the equation:

$$
\Delta \Theta_{K}(t)=(1.58382 E-2) \cdot k_{M} \cdot \Theta_{0}^{2}(t)+(3.28617 E-4) \cdot k_{M} \cdot \Theta_{0} \Theta_{0}(t)
$$

and is dependent on basic technology parameters only, so it mean that one can apply it directly to the CNC machine control program or to the simulation environment (Fig. 5). 




Fig. 5. Cubic function coefficient best fitted with linear functions

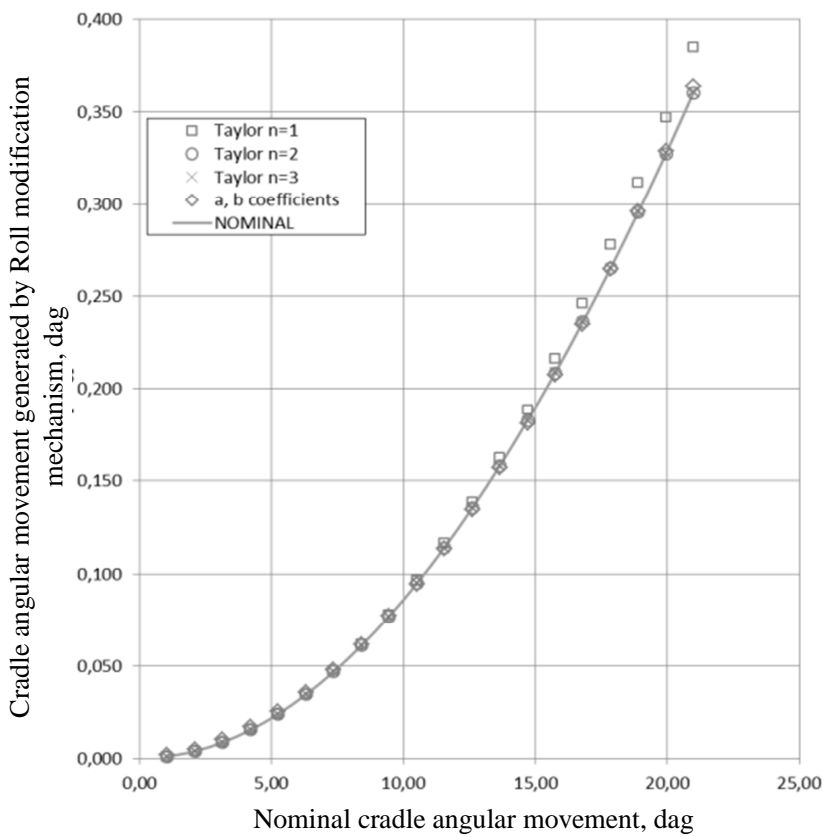

Fig. 6. Comparison of different mathematical models accuracy 
On the basis of fundamental mathematical relationships, we can try to solve the equation (9):

$$
\Delta \Theta_{K}=\frac{E_{M}}{r_{K}} \cdot\left(1-\cos \Theta_{R C}\right)
$$

by expanding the cosine function in a Taylor series:

$$
\cos \Theta_{R C}=\sum_{n=0}^{\infty} \frac{(-1)^{n}}{(2 n) !} \Theta_{R C}{ }^{2 n}=1-\frac{\Theta_{R C}{ }^{2}}{2}+\frac{\Theta_{R C}{ }^{4}}{24}-\frac{\Theta_{R C}{ }^{6}}{720}+\ldots
$$

In the simplest case when the factor, $n=0$ the value of the roll modification $\Delta \Theta_{K}=0$, so the modification does not occur.

Increasing the factor value to $n=1$ leads to the relation:

$$
\underset{n=1}{\Delta \Theta_{K}}=\frac{E_{M}}{r_{K}} \cdot \frac{\Theta_{R C}^{2}}{2}
$$

that can be simplified, using equations 1 to 4 , to:

$$
\Delta \Theta_{K=1}=k_{M} \cdot \Theta_{0}^{2}(t)
$$

This solution is very plain and convenient since it requires only 1 basic technology parameter.

For $n=2$ roll modification expression takes the form:

$$
\underset{n=2}{\Delta \Theta_{K}}=\frac{E_{M}}{r_{K}} \cdot\left(\frac{\Theta_{R C}^{2}}{2}-\frac{\Theta_{R C}{ }^{4}}{24}\right)
$$

and also can be simplified to:

$$
\underset{n=2}{\Delta \Theta_{K}}=k_{M} \cdot\left(\Theta_{0}^{2}(t)-\left(\frac{100}{\Theta_{0}}\right)^{2} \cdot \frac{\Theta_{0}{ }^{4}(t)}{12}\right)
$$

but now it requires additional basic technology parameter to provide a solution as well as a more complex calculus. 
For $n=3$ equation is as follows:

$$
\underset{n=3}{\Delta \Theta_{K}}=\frac{E_{M}}{r_{K}} \cdot\left(\frac{\Theta_{R C}^{2}}{2}-\frac{\Theta_{R C}^{4}}{24}+\frac{\Theta_{R C}^{6}}{720}\right)
$$

and the simplified version:

$$
\underset{n=3}{\Delta \Theta_{K}}=k_{M} \cdot\left(\Theta_{0}{ }^{2}(t)-\left(\frac{100}{\Theta_{0}}\right)^{2} \cdot \frac{\Theta_{0}{ }^{4}(t)}{12}+\left(\frac{100}{\Theta_{0}}\right)^{4} \cdot \frac{\Theta_{0}{ }^{6}(t)}{360}\right)
$$

In this case, it still requires 2 basic technology parameters to provide the final solution, but calculations are even more complex.

Of course the higher the $n$ parameter in Taylor series expansion, the more accurate the function adjustment. However, it is important to keep in mind that roll modification mechanism does not operate in the full $\langle 0 ; 2 \pi\rangle$ cosine's range, but in the narrowed $\left\langle 0 ; \frac{5 \pi}{18}\right\rangle$ range (Fig. 6).

\section{Conclusions}

Two types of mathematical models have been presented in this paper: purely mathematical based on Taylor series expansion and experimental, based on nominal points approximation. Figure 6 presents the accuracy comparison of all considered approaches. Despite the fact that model obtained from Taylor series expansion with parameter $n=1$ (equation 17) is convenient and simple in application (it requires only one parameter and very simple calculus), it generates the biggest mistake of all presented. For evaluated gearset and for industrial practice examples this error varies between 0 and $0.1 \%$. Remaining models generate quite accurate solution with an error level of less than $0.01 \%$ when comparing to nominal. Experimental solution described by equation 13 seems to be the desired one, since it requires the lowest computational resources and is the easiest to implement.

As mentioned before, the roll modification mechanism mathematical model can be applied directly into numerical machine control units as well as in geometric simulation environments. Figure 7 presents the pinion geometry generated from Table 2 settings, but with the artificially increased roll modification coefficient. This geometry is a "dummy" example, but it clearly illustrates the roll modification mechanism impact on the teeth flank geometry. 
In the industrial practice, material excesses $(\Delta h, \Delta s)$ formed during the modified roll process varies, depending on the transmission size, from a few hundredths to a few tenths of a millimeter.

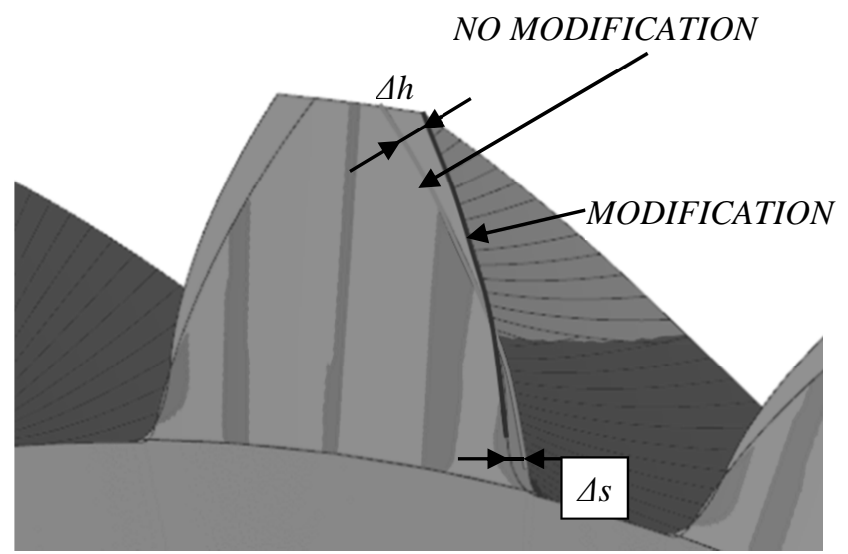

Fig. 7. Example of geometry simulation environment use (CC flank only)

\section{Acknowledgement}

Financial support of Structural Funds in the Operational Programme - Innovative Economy (IE OP) financed from the European Regional Development Fund - Project No POIG.0101.02-00-015/08 is gratefully acknowledged.

\section{References}

[1] F.L. LITVIN, A. FUENTES: Gear geometry and applied theory. University Press, Cambridge 2004.

[2] W.N. KIEDRYŃSKI, K.M. PISMANIK: Obróbka stożkowych kół zębatych, Państwowe Wydawnictwa Techniczne, Warszawa 1961.

[3] P. SKAWINSKI: Integracja projektowania i wytwarzania kół zębatych stożkowych o zębach kołowo-łukowych. Oficyna Wydawnicza Politechniki Warszawskiej, Warszawa 2010.

[4] P. SKAWINSKI: Computer integrated design and manufacturing of spiral and hypoid bevel gears. Proc. XI Inter. Conference "Computer Simulation in Machine Design - COSIM2006”, Krynica Zdrój 2006.

[5] P. SKAWINSKI: Computerized integration of design and manufacturing of spiral and hypoid bevel gears. Proc. XVII Inter. Conference FAIM2007, Philadelphia 2007.

[6] H.J. STADTFELD: Handbook of bevel and hypoid gears. Rochester Institute of Technology, Rochester 1993.

[7] Z. WOJCIK: Przekładnie stożkowe. WNT, Warszawa 1984. 